\title{
Public health relevance of drug-nutrition interactions
}

\author{
Szabolcs Péter ${ }^{1}$ - Gerjan Navis ${ }^{2}$ Martin H. de Borst ${ }^{2}$ - Clemens von Schacky ${ }^{3,4}$. \\ Anne Claire B. van Orten-Luiten ${ }^{5,6} \cdot$ Alexandra Zhernakova $^{2} \cdot$ Renger F. Witkamp $^{5}$. \\ André Janse $^{6} \cdot$ Peter Weber $^{1,7} \cdot$ Stephan J. L. Bakker ${ }^{2}$ - Manfred Eggersdorfer ${ }^{1,2}$
}

Published online: 26 July 2017

(C) The Author(s) 2017. This article is an open access publication

\begin{abstract}
The public health relevance of drug-nutrition interactions is currently highly undervalued and overlooked. This is particularly the case for elderly persons where multi-morbidity and consequently polypharmacy is very common. Vitamins and other micronutrients have central functions in metabolism, and their interactions with drugs may result in clinically relevant physiological impairments but possibly also in positive effects. On 12 April 2016, the University Medical Center Groningen (The Netherlands), as part of its Healthy Ageing program, organized a workshop on the public health relevance of drug-nutrient interactions. In this meeting, experts in the field presented results from recent studies on interactions between pharmaceuticals and nutrients, and discussed the role of nutrition for elderly, focusing on those persons receiving pharmaceutical treatment. This
\end{abstract}

Szabolcs Péter

szabolcs.peter@dsm.com

1 DSM Nutritional Products Ltd., Wurmisweg 576, 4303 Kaiseraugst, Switzerland

2 University of Groningen, University Medical Center Groningen, Hanzeplein 1, 9713 GZ Groningen, The Netherlands

3 Preventive Cardiology, Medizinische Klinik und Poliklinik I, Ludwig Maximilians-Universität München, Ziemssenstr. 15, 80336 Munich, Germany

4 Omegametrix GmbH, Am Klopferspitz 19, 82152 Martinsried, Germany

5 Division of Human Nutrition, Wageningen University, Stippeneng 4, 6708 WE Wageningen, The Netherlands

6 Department of Geriatric Medicine, Hospital Gelderse Vallei, Willy Brandtlaan 10, 6716 RP Ede, The Netherlands

7 University of Hohenheim, Schloß Hohenheim 1, 70599 Stuttgart, Germany paper summarizes the proceedings of the symposium and provides an outlook for future research needs and public health measures. Since food, pharma and health are closely interconnected domains, awareness is needed in the medical community about the potential relevance of drug-nutrition interactions. Experts and stakeholders should advocate for the integration of drug-nutrition evaluations in the drug development process. Strategies for the individual patients should be developed, by installing drug review protocols, screening for malnutrition and integrating this topic into the general medical advice.

Keywords Public health - Drug-nutrient interactions . Micronutrient deficiency $\cdot$ Microbiota $\cdot$ Health benefits

\section{Introduction}

The University Medical Center Groningen (UMCG, The Netherlands) organizes yearly symposia on different, actual topics in the overlapping fields of medicine and nutrition as part of its Healthy Ageing program. Over the past number of years this event evolved to a thinktank, resulting in several publications, educational- and research collaborations [1-3]. The aim of the 2016 meeting that took place on 12 April at the UMCG was to evaluate the role and impact of drug-nutrition interactions for people using medication, especially the elderly. The focus was on current drugs, however, with the ambition to also provide input for future drug development by engaging experts from both academy and industry. The overall goal of the meeting was to create awareness, to provide an overview of this topic and to foster collaborative activities. Drug-nutrient interactions are often preventable or curable, provided that they are recognized in an early 
stage. Therefore, more insight in this matter will contribute to an improved health and well-being of patients. This paper summarizes the main messages and conclusions of the presentations and following discussions and advocates to take actions and integrate the topic "drug-nutrition interactions" in scientific research programs and in clinical practice.

\section{Clinical assessment of interactions of drugs with nutrients: an urgent unmet need}

Whereas drug-drug interactions are widely recognized as clinically relevant and are included in most pharmacovigilance systems, nutrient-drug interactions are underexplored, and their assessment is not part of the clinical routine. Yet, there is ample data supporting the presence and relevance of nutrient-drug interactions, indicating that a systematic assessment would be necessary.

The poor translation of results from randomized clinical pharmacological trials to real life is one of the major challenges in medicine of the twenty-first century, as noted in the Lancet series: "Increasing value, reducing waste" [4]. Variation in-non-documented-environmental interacting factors, such as nutrients, or adverse drug effects on nutrient status, may be among the contributing factors. This becomes an even more urgent issue in the era of ageing societies, with a steady increase in the number of elderly with multimorbidity and hence increasing prevalence of polypharmacy [5] (Table 1). Awareness should be created that multimorbidity is no longer a confounder but the focus in this age group [6]. In general, pharmacotherapy is approached as the sum of separate medicinal treatments where multi-level interactions are not tested, and as such is poorly suited to the needs of the ageing individual. High costs, several adverse effects, conflicting guidelines are involved and this complexity makes it prone to multiple errors. Examples of specific interactions have been recently summarized and discussed elsewhere [7].

Table 1 Effects of polypharmacy on nutritional status

\begin{tabular}{ll}
\hline Effect on & Effect by \\
\hline Food intake & $\begin{array}{l}\text { Gastrointestinal discomfort/poor appetite } \\
\text { Gastrointestinal digestion/absorption }\end{array}$ \\
& $\begin{array}{l}\text { Central nervous system depression } \\
\text { Gastrointestinal malabsorption }\end{array}$ \\
$\begin{array}{l}\text { Nutrient absorption } \\
\text { tion of nutrients }\end{array}$ & $\begin{array}{l}\text { Organ impairment (liver, kidney) } \\
\text { Loss of nutrients essential to metabolism }\end{array}$ \\
\hline
\end{tabular}

\section{Drug-nutrition interactions as adverse drug reaction}

\section{Adverse drug reactions (ADRs)}

Medication-related health problems are a public health issue of major relevance, especially in elderly people. In the Western world, unintended, negative effects of drug use would be cause number three of mortality, immediately after cardiovascular disease and cancer. In the European Union, drug side effects are estimated to be responsible for 197,000 deaths per year [8]. The risk of adverse drug reactions (ADRs) increases with advancing years [9]. This can be explained by age-related changes in pharmacokinetics and pharmacodynamics, the increased vulnerability of elderly people, and by the high prevalence of multi-morbidity and consequently polypharmacy in this age group [10], as the number of medications used is the most important predictor of the risk of ADRs [7, 9] (Fig. 1). Median prevalence of adverse events for elderly in ambulatory care is reported to be $23 \%$ (IQR 19-31\%) [11]. Prevalence of ADR-related hospital admissions of 75+ years subjects are estimated to be $10 \%$ (IQR $8-13 \%$ ), of which $40 \%$ could have been prevented [12]. These figures may be underestimations, as $94 \%$ of the potential ADRs are suspected not be reported by health care practitioners, according to a systematic review of drug surveillance data from 12 countries [13]. Also in the premarketing phase, risk assessment has its limitations: drug development lines may be too short for long-term effects to become clinically manifest and the number of patients during the application phases is generally insufficient to adequately detect rare events [14]. Moreover, children, premenopausal women, and, elderly subjects are underrepresented in premarketing trials, just as patients having more than one disease and/or using more medications simultaneously.

\section{Drug-nutrition interactions (DNIs)}

However, evaluation of drug safety before and after drug approval is principally about the consequences of single drugs or interactions between drugs. With exception of the effects of whole meals and macronutrients on drug action, drug-nutrition interactions (DNIs) are not specifically addressed during the drug development phase [15]. Recognition of DNIs is often hampered by limited nutritional knowledge among researchers and professionals in the health care field: Nutrition education in EU medical schools is between 0.5-3 days, and in the US about 2.5 day [16-18]. The lack of nutritional expertise is a plausible contributor to the already substantial underreporting of ADRs. Although drug and supplement use is increasing [19], and in particular in elderly populations, prevalence 
Fig. 1 Increased risk of adverse drug reactions in older people

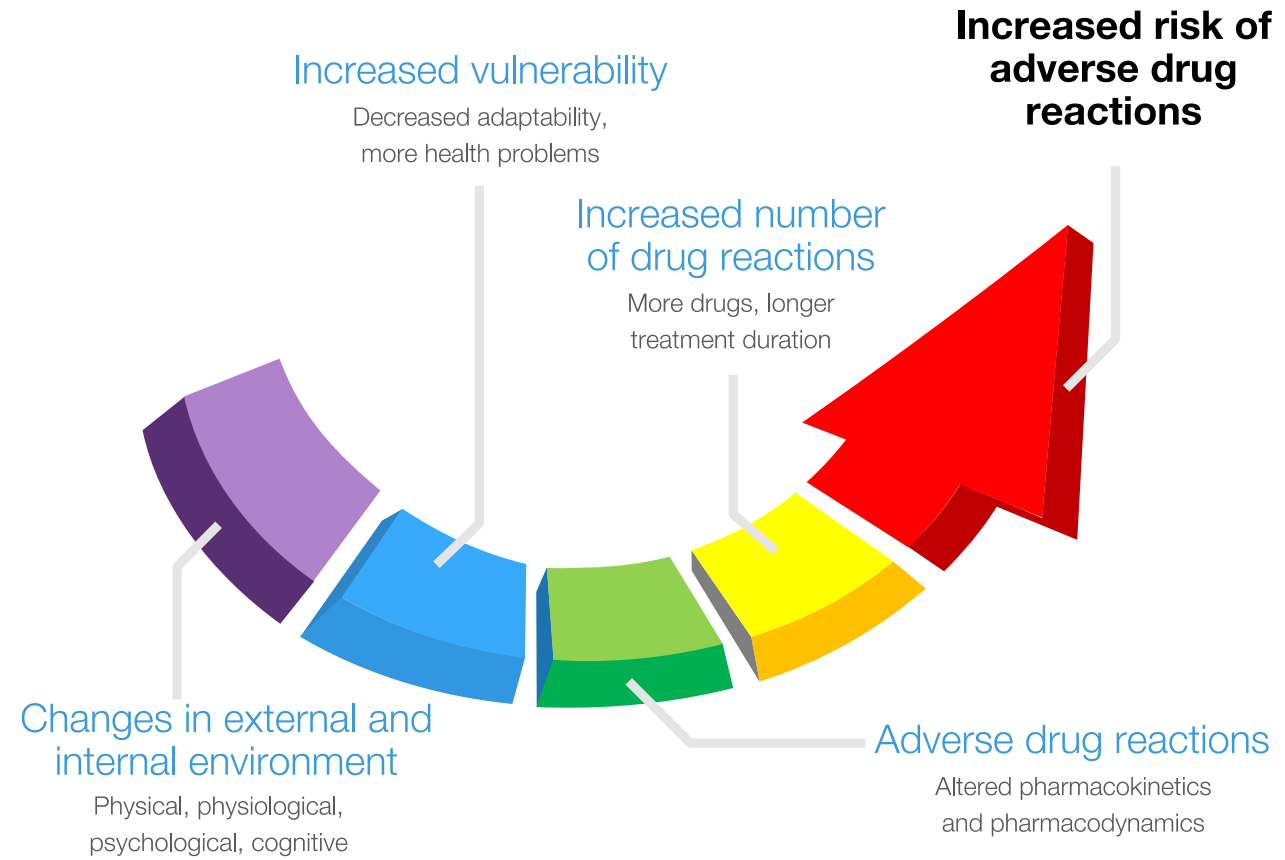

of polypharmacy and malnourishment is high [20], we can only speculate about the clinical relevance and public health impact of interactions between drugs and nutritional determinants. Theoretically, however, the impact on public health might be substantial, considering the clinical relevance of minimal adverse drug effects and an adequate nutritional status for health and well-being.

\section{Tool to structure DNIs}

A helpful tool to address the relatively unexplored domain of DNIs is a classification framework for categorizing DNIs. A first distinction is made between the effects of meals, individual foods, specific nutrients or nutrition status on drug action, and vice versa, the effects of drug use on determinants of nutrition status $[15,21]$ :

- Class 1-effect of obesity and malnutrition on drug action,

- Class 2-effect of nutrition on drug action,

- Class 3-effect of specific nutrients or dietary supplements on drug action,

- Class 4-effects of drugs on nutrition status,

- Class 5-effects of drugs on nutrient status.

Class 1 DNIs are about the impact of overweight or malnourishment on drug action. A Class 2 DNI is illustrated by dietary fat and lapatinib, a protein kinase inhibitor for the treatment of metastatic breast cancer. Compared to fasting, the bioavailability of this antineoplastic agent increases by $168 \%$ after a low fat meal and by $325 \%$ after a high fat meal
[22]. Bioavailability of abiraterone, a CYP17 inhibitor for the treatment of metastatic prostate cancer, even increases tenfold after a high fat meal [23]. These Class 2 interactions may ultimately be related to considerable cost savings in cancer treatment [22], as the drug leaflets of these oncology drugs indicate that the medication should be taken without any food. Class 3 DNIs initiated by the concurrent use of drugs and supplements may have advantages as well as risks [24]. Beneficial are the increased plasma levels of chemoresistance-inducing fatty acid 16:4(n-3) observed in human volunteers after consumption of fish and fish oil [25]. Oppositely, calcium chelating with a tetracycline medication in the gastrointestinal tract is a wellknown example of an undesirable Class 3 interaction. The Dutch pharmacovigilance Centre Lareb, however, received only 55 reports of these adverse food-drug interactions over 25 years (1991-2014), which makes it likely that Class 3 DNIs are underreported [26]. Class 4 DNIs refer to the effects of drugs on nutrition status on macrolevel, which are influenced by a diversity of determinants: from the ability to see, smell, taste, eat, and drink, until the final excretion of urine and feces. Several publications report inverse associations of polypharmacy and use of specific drug groups with risk of malnourishment [27, 28]. The last category, Class 5 DNIs are about the links between drug use and nutrient status. In a sub-cohort of 631 geriatric outpatients of the Dutch PanDeMics study, for example serum 25-hydroxyvitamin D (25(OH)D) was $10 \mathrm{mmol} / \mathrm{l}$ lower $(p=0.01)$ in male subjects using $\geq 10$ medications compared to males using fewer medications. Severe polypharmacy was present in $21 \%$ of the male patients. Also 
use of oral antidiabetics, vitamin $\mathrm{K}$ antagonists, diuretics, and ACE inhibitors was found to be significantly associated with lower vitamin D levels [29]. Depending on the cut-off value, prevalence of vitamin $\mathrm{D}$ deficiency in this cohort was $50 \%(25(\mathrm{OH}) \mathrm{D}<50 \mathrm{nmol} / \mathrm{l})$ or $76 \%(25(\mathrm{OH}) \mathrm{D}$ $<75 \mathrm{nmol} / \mathrm{l})$. Other drugs, clearly affecting circulating vitamin D are anti-epileptics, anti-oestrogens, anti-virals, glucocorticosteroids and bisphosphonates [30]. By taking the pharmacological mechanism and localization of the interaction into account, the individual classes can be further split up into subclasses $[15,21]$.

\section{Interaction between oral contraceptives and folate}

Neural tube defects (NTDs) are a group of congenital birth defects that affect the central nervous system; the most common types of NTD are spina bifida and anencephaly. Neural tube closure takes place between 24 and 28 days after conception, thus NTD's occur very early in pregnancy, even before most women know that they are pregnant. Each year, ca. 300,000 babies are born with NTD globally, while in Europe ca. 4500 pregnancies are affected. Regional prevalence varies considerably due to differences in environmental (e.g., dietary) and genetic factors [31]. In a study, conducted in Dutch school-aged children whose mothers had low folate status during early pregnancy, cognitive development was assessed. Low prenatal folate levels were associated with smaller total brain volume, poorer language performance, reduction in memory and learning, and decrease in visio-spatial domains. These results indicated that insufficient folate status in early pregnancy had longlasting effects on the offspring's cognitive development [32]. A review article examined whether folate supplementation before and during early pregnancy could reduce NTD and other birth defects without causing adverse outcomes for mothers or babies. Authors concluded that folic acid, alone or in combination with other vitamins and minerals, prevented NTD and was safe for the mothers and newborns [33]. Furthermore, a dose-response study on red blood cell (RBC) folate during pregnancy was conducted: RBC folate levels of $\geq 906 \mathrm{nmol} / \mathrm{L}(=400 \mathrm{ng} / \mathrm{mL})$ were identified as providing the greatest protection from NTD, however, insufficient data was available to calculate the risk reduction for levels $\geq 1292 \mathrm{nmol} / \mathrm{L}$. It was also shown that a doubling of the RBC folate level is achievable with an increased folic acid intake of $0.4 \mathrm{mg}$ per day. Importantly, it was also estimated that a $48 \%$ reduction in the total NTD rate was achievable with an increased population intake of $0.4 \mathrm{mg}$ per day of folic acid [31, 34].

Surveys indicate that only a small proportion of women take folic acid supplements during the periconceptual period [31], and this is complicated by the issue that folate status is generally low in women. Current recommendations in the US and Europe propose that all women planning or capable of pregnancy should take folic acid supplements at doses of $0.4 \mathrm{mg} /$ day, commencing at least one month before conception. However, implementation of these recommendations is unsatisfying: Only $24 \%$ of women of childbearing potential consume the recommended intake of folic acid in the US. After the introduction of public folic acid awareness campaigns in the UK, The Netherlands, and Australia, post-campaign rates of folic acid supplement use were below $50 \%$ of women of childbearing potential. In addition, there is evidence that use of oral contraceptives (OC) may reduce folate status. A systematic review and meta-analysis of the effect of oral contraceptive use on plasma and RBC folate concentrations showed that independently of $\mathrm{OC}$ use, almost all studies reported much lower mean RBC folate values than the protective cut-off levels. However, the mean difference in RBC folate concentrations between OC-users vs. non-users was clinically significant [35]. It is known that oral contraceptive use can lead to low serum and tissue concentrations of folate, but the mechanism of this effect is uncertain. According to some hypotheses, OC may interfere with the absorption of pteroylpolyglutamates or might cause malabsorption of dietary folate by inhibition of jejunal folate conjugase, however, this was not confirmed by in vitro studies. Oral contraceptive users have normal folate absorption but show increased serum clearance and urinary excretion of folates. A possible mechanism for increased folate excretion would be a change in serum binding proteins for folate. Low serum folate in OC users could also be explained by enzyme induction in the liver [36]. Estrogen levels of OC were consequently reduced from $150 \mu \mathrm{g}$ in the 1960 s to $20-50 \mu \mathrm{g}$ after 1988 , while many of the studies were conducted in the 1970s and evidence from trials using modern OC is very limited. Also, little information is available on confounders such as dietary folate. Wilson et al. states that insufficient data is available for a definitive conclusion regarding the effect of modern OC on folate status [37]. However, based on the above it is clearly confirmed and evident, that folate status in women of reproductive age should be adequate as neural tube closes before pregnancy (Fig. 2).

It has been proposed that folate-fortified $\mathrm{OC}$ are an efficient way to maintain adequate blood folate levels for women of reproductive age [31]. In an RCT, women received $\mathrm{OC}$ with folate or $\mathrm{L}$-5-methyltetrahydrofolate (L-5-MTHF) for 24 weeks and $\mathrm{OC}$ alone for an additional 20 weeks (folate elimination phase). An OC fortified with folate or L-5-MTHF for 6 months lead to a significant increase and maintenance in folate status in women of reproductive age $[38,39]$. Co-administration of folate with OC increased RBC folate levels above 'NTD-protective' threshold of $>906 \mathrm{nmol} / \mathrm{L}$ within eight or ten weeks after 


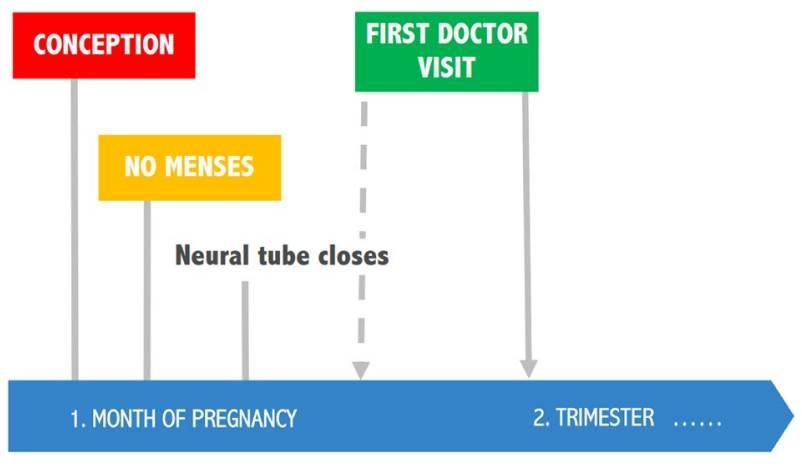

Fig. 2 Folate status in women of reproductive age should be adequate to prevent neural tube defects (NTDs)

commencement of regular use of L-5-MTHF or folate, respectively. The protective levels were maintained for 10 or 8 weeks after cessation of intake for L-5-MTHF or folate, respectively [40]. Thus, folate-fortified OC have the potential to protect against NTD, especially considering that about half of the pregnancies are unplanned, $21.1 \%$ of women become pregnant in one menstrual cycle after stopping OC use and $45.7 \%$ conceive within three cycles after stopping OC use.

\section{Interaction of vitamin $D$ and vitamin $K$ to prevent calcification}

Despite the availability of lifestyle and pharmacological interventions targeting cardiovascular risk factors including hypertension, hypercholesterolemia, and diabetes, their efficacy to reduce cardiovascular risk is limited. This particularly applies to high-risk populations such as patients with chronic kidney disease [41]. The resulting high residual cardiovascular risk underscores the need to identify and target additional pathways. Vascular calcification contributes to stiffening of the vasculature, which is a main driver of cardiovascular diseases including heart failure with preserved ejection fraction (HFpEF). Vascular calcification is a complex process directed by the interplay between proand anti-calcification factors. Vitamin D and $\mathrm{K}$ both influence the process of vascular calcification. Although not a classical example of drug-nutrition interactions, the various preventive and therapeutic applications of both nutrients qualify the case for further elaboration within the context of this article.

Animal studies suggest that vitamin D plays a key role in the prevention of vascular calcification. Vitamin D receptor knockout mice display vascular calcification [42], and treating animals prone to develop calcifications with vitamin D provides vascular protection [43]. Importantly, exposing animals to excessive amounts of vitamin D (receptor activators) may have adverse effects, with enhanced vascular calcification [43]. This is a warning sign also observed in patients; a recent analysis of the PREVEND cohort showed that, although an inverse association between $25(\mathrm{OH})$ vitamin $\mathrm{D}$ and the risk of hypertension was observed, the opposite was the case for the active metabolite $1.25(\mathrm{OH}) 2$ vitamin D [44]. Each 1-SD decrement of $1.25(\mathrm{OH}) 2$ vitamin $\mathrm{D}$ was associated with a $10 \%$ lower hypertension risk, independent of potential confounders. The same dilemma was observed in the ViRTUECKD trial, which demonstrated that the vitamin D receptor activator paricalcitol lowers albuminuria in chronic kidney disease patients, but at the same time increases markers of deregulated phosphate homeostasis (i.e., fibroblast growth factor 23) and vascular calcification propensity [45]. Overall, it seems that (25-OH) vitamin D deficiency has the most relevant impact on clinical outcomes. A recent large meta-analysis showed that in the elderly, vitamin D deficiency is associated with a higher risk of cardiovascular mortality [46]. In the general population, the need for vitamin D supplementation to prevent mortality remains a matter of debate. In a Cochrane meta-analysis including data from 56 RCTs containing overall 95,286 participants, it was found that cholecalciferol (vitamin D3), but not ergocalciferol (vitamin D2), alfacalcidol or calcitriol reduced mortality upon long-term (mean 4.4 years) treatment [47]. The authors calculated that 150 people need to be treated with vitamin D3 over five years to prevent one additional death, which may seem reasonable from a public health perspective. In contrast, a recent trial sequential meta-analysis suggested a limited effect of vitamin D supplementation on non-skeletal outcomes [48]. However, the methodology used in this paper has been heavily criticized in the scientific community [49-51].

The vitamin K-dependent matrix-gla protein (MGP) is among the most powerful endogenous calcification inhibitors [52]. Several animal studies have shown that vitamin $\mathrm{K}$ insufficiency contributes to vascular calcification, which can be reversed by vitamin K supplementation [53-55]. In a state of vitamin $\mathrm{K}$ insufficiency, undercarboxylated MGP species including desphospho-undercarboxylated MGP (dp-ucMGP) are elevated in the circulation. Epidemiological studies have consistently shown independent associations of high circulating dp-ucMGP levels with both arterial stiffness [56] and adverse cardiovascular outcomes in high-risk patients including patients with aorta valve stenosis [57], cardiovascular disease [58], CKD [59], and renal transplant recipients [60]. Currently, ongoing clinical trials addresses the effect of vitamin $\mathrm{K}$ supplementation on vascular calcification in hemodialysis patients [61] and patients with coronary artery disease [62]. Higher vitamin $\mathrm{K}$ intake reduced dp-ucMGP [63], and has been associated with a lower risk of aorta calcification and (cardiovascular 
and all-cause) mortality in the general population. These observations suggest that increasing vitamin $\mathrm{K}$ intake could be a successful strategy to reduce cardiovascular risk [64].

Little is known about the interplay between vitamins D and $\mathrm{K}$ in relation to vascular calcification. The availability of a novel serum calcification propensity assay [65] will importantly facilitate studies prospectively addressing calcification risk. A higher calcification propensity has consistently been associated with a higher (cardiovascular) mortality risk in patients with CKD [66] and renal transplant recipients [67]. An integrated nutritional intervention, including the targeting of vitamin $\mathrm{D}$ and $\mathrm{K}$ deficiencies, may eventually turn out to be the most fruitful approach to retard vascular calcification and improve cardiovascular prognosis in high-risk patients.

\section{Omega-3 benefits}

Previously, conventional research in nutrition has focused on dietary intake of the two marine omega-3 fatty acids eicosapentaenoic acid (EPA) and docosahexaenoic acid (DHA). However, this approach has inherent methodological issues: Food Frequency Questionnaires often result in implausible data, look up tables are usually outdated and issues of bioavailability, like inter-individual variability or dependency on matrix effects are ignored [68-71]. It is no wonder that there is no agreement of recommendations on this basis [72].

It is known that EPA and DHA content of many cells is reflected in erythrocytes, therefore, erythrocyte EPA plus DHA is used as a biomarker with low biological variability for the status of an individual in these two fatty acids. On this basis, a standardized analytical procedure, validated for 26 fatty acids, with low analytical variability has been established: The "HS-Omega-3 Index ${ }^{\circledR}$ " [73]. It is supported by the largest database of all methods of fatty acid analyses, backed up by 212 publications and $>50$ ongoing research projects. The HS-Omega-3 Index is representative for heart and breast tissues in humans, and in experimental animals it is representative for kidney, cerebral cortex, liver, lung and gut tissues; there is almost no correlation with intake $[69,74-77]$. A target range for the HSOmega-3 Index has been defined as $8-11 \%$ EPA plus DHA in total erythrocyte fatty acids [78]. Lower levels are associated with increasing risk for total mortality and cardiovascular events like fatal and non-fatal myocardial infarction, sudden cardiac death, development of and death from congestive heart failure [78]. Determining the HS-Omega-3 Index in addition to assessing conventional risk factors provides incremental information, and individuals at medium risk for cardiovascular events can be reclassified into the high or the low risk category. This can be then the basis of a therapeutic consequence. Increasing the HS-Omega-3 Index caused improvements in surrogate and intermediate parameters in pertinent intervention trials (Fig. 3). According to the criteria of the American Heart Association, the HS-Omega-3 Index is a novel biomarker for cardiovascular risk. Among diseases associated with low omega-3 levels are hypertension, congestive heart failure, atrial fibrillation, coronary artery disease, and peripheral atherosclerosis [78].

In contrast, a series of meta-analyses on large intervention trials with EPA and DHA did not find reductions in mortality or cardiovascular events. In the pertinent trials, EPA and DHA were frequently given as capsules at breakfast, thus inadvertently minimizing bioavailability. Moreover, participants were recruited irrespective of baseline
Fig. 3 Effects of increasing the HS-Omega-3 Index on surrogate parameters

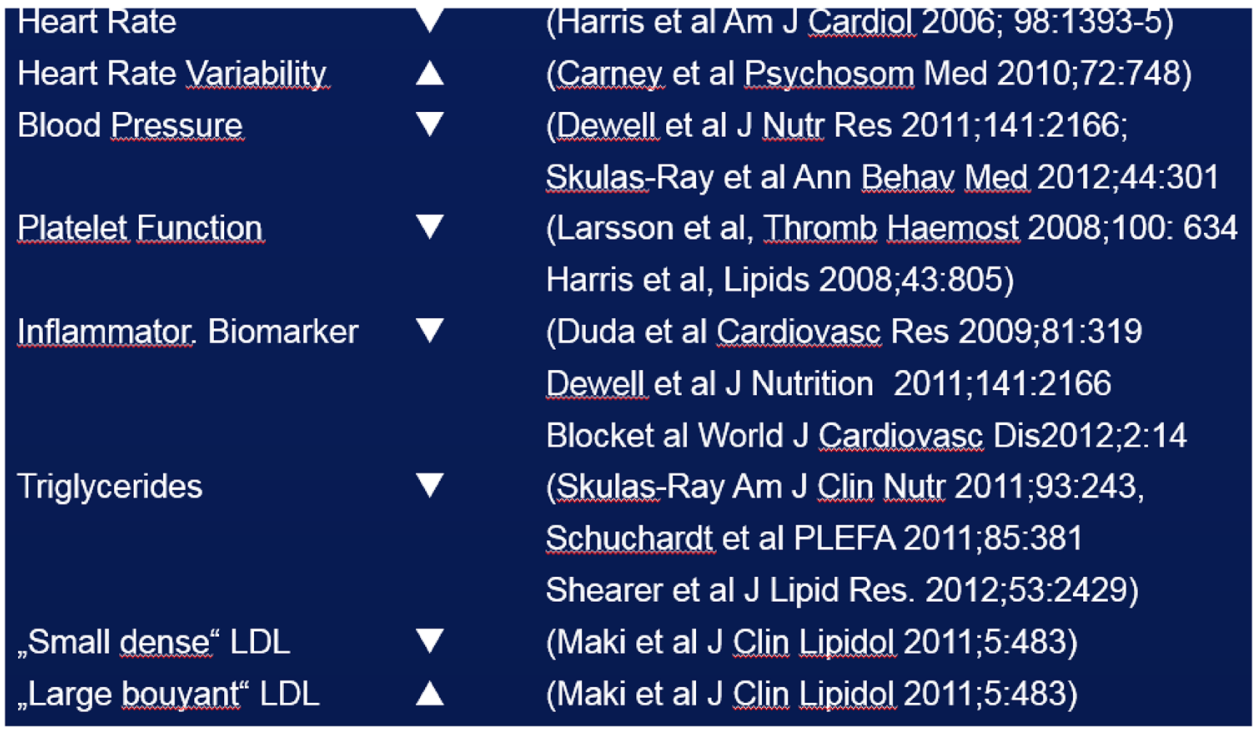


levels of EPA and DHA, and the large inter-individual variability in uptake of EPA and DHA was unknown. As demonstrated in one large trial, this design leads to overlapping levels of EPA and DHA throughout the study [79]. Low bioavailability and overlapping levels are thought to contribute substantially to neutral outcomes of many large trials [78]. This is supported by the fact that trials maximizing bioavailability using fatty fish as a source for EPA and DHA, or trials in patients with low baseline levels (e.g., in patients with congestive heart failure) or trials using high doses had positive results [80-82]. However, to convince cardiologists, a new generation of HS-Omega-3 Indexbased large intervention study in the cardiovascular area is probably needed.

A low HS-Omega-3 Index or low levels of EPA and DHA in other fatty acid compartments can also be found in issues of brain health: Poor brain development (structure and function), attention-deficit-hyperkinetic disorder (ADHD), poor social behavior, emotional lability, major depression, suicide or cognitive decline (memory, reaction time, executive function) and others [83-85]. Trials using higher doses of EPA and DHA (e.g. $>750 \mathrm{mg}$ DHA/day) usually had positive results in these issues of brain function, as substantiated by a series of pertinent meta-analyses [86]. Of note, brain structure and function was found to be improved in healthy individuals.

Furthermore, a low HS-Omega-3 Index or low levels of EPA + DHA are associated with an increased risk for a number of other conditions like stroke [87], osteoporosis [88], rheumatoid arthritis [89], psychopathology and aggression [90], or delayed onset muscle soreness [91]. Since sources of EPA and DHA disappear from our diet and endogenous synthesis is impossible, on a population level symptoms of a deficit become more frequent. When studied, e.g., by national statistic administrations, $>80 \%$ of the populations had a HS-Omega-3 Index below the target range of $8-11 \%$ [92]. The dogma that for healthy people, eating a normal diet, food supplements are unnecessary is wrong in this case [93]. The health of heart, brain and some other organs depends on a sufficient status in EPA and DHA. The widespread deficit in EPA + DHA can thus be conveniently diagnosed and safely treated.

It is well-established, that lipid-lowering therapy with statins can significantly reduce the incidence of cardiovascular disease and the risk of coronary events. However, aggressive lowering of LDL cholesterol by statins comes with the risk of lowering polyunsaturated fatty acid (PUFA) concentrations as well [94], and mitigating the health benefits of omega-3 fatty acid supplementation [95]. Considering the widespread use of this drug group and the inadequate omega-3 PUFA status of many people worldwide [96], it is possible that statin use may be one contributing factor to that situation. The residual risk of cardiovascular events after treatment with statins might be explained in part by the low n-3 PUFA status of patients [97]. Furthermore, a clinically significant additive effect for most cardiovascular events was observed for n-3 PUFAs in patients on statin treatment [98]. Even though statins are established as one of the leading treatment forms to reduce CVD risk, it appears that there is an opportunity to further reduce this risk by omega-3 PUFA.

Based on mechanistic data, and some case reports, concerns have been raised that high doses of omega- 3 fatty acids predispose to bleeding events [99, 100]. These concerns, however, could not be substantiated by clinical data:

- in all trials with omega-3 fatty acids in cardiovascular patients (with a total of $>75,000$ participants), most participants were using some kind of platelet inhibitor like aspirin [78, 101]. Although a safety issue included in the study protocols, increased bleeding was not reported from the omega-3 groups [78, 101].

- a total of 826 patients on phenprocoumon because of a thromboembolic event aged $\geq 65$ years were observed for 3 years. Patients in the highest tertile of their Omega-3 Index lived longer than patients in the lower tertiles, but bleeding events were evenly distributed among tertiles [102].

- a total of 1523 patients with an acute myocardial infarction were treated with platelet inhibitors, anticoagulants and a number of other agents, as demanded by current guidelines. Bleeding events had no relation to the Omega-3 Index of these patients [103].

- intravenous omega-3 fatty acids given before an operation rather improved outcome, but had no effect on bleeding [104, 105].

- the US-American Federal Drug Administration regards up to $3 \mathrm{~g} /$ day of EPA plus DHA as safe (Docket No. 91N-0103), while its European counterpart considers up to $5 \mathrm{~g} /$ day of EPA as safe (http://www.efsa.europa.eu/ en/press/news/120727.htm).

Taken together, although a clinically relevant interaction between drugs affecting platelet function and/or the coagulation system and the nutrient omega-3 fatty acids has been claimed, systematic data and regulatory authorities do not support this claim. Thus, this interaction remains to be proven.

\section{Drugs and disturbance of microbiota}

It is estimated that in the human body, there are approximately the same number of bacterial cells as human cells. The human gut microbiome is a complex ecosystem that is considered to be both an immune and a metabolic organ. 
Genes, lifestyle, medication, nutrients and their metabolites all influence gut microbiota, however, the effect of this interaction on disease development is uncertain. Nevertheless, several bacteria have been associated with many diseases [106-109] and fecal transplantation is already an emerging method to treat certain conditions.

In the recent years, population cohorts of healthy individuals have been applied for the analysis of multiple factors influencing microbiota composition. The LifeLines observational follow-up study encompasses in total 165,000 individuals within a 3-generation design. Data collection is complete for multiple questionnaires, different biologi$\mathrm{cal}$, and phenotype information. A follow-up questionnaire is filled out every year, completed with screening every 5 years for a total duration of 30 years $[110,111]$. The LifeLines-DEEP project collects extra "omics" data in a subset of the cohort $(n=1500)$, e.g., genome-wide polymorphisms and different metabolites, and analyses the relation between various internal and environmental factors and the microbiome. Within this project, it has been shown that due to the differences in these factors, microbiome composition is highly variable across individuals [112] (Fig. 4).

Further analyses revealed that drugs like proton pump inhibitors (PPI), statins and antibiotics considerably affect gut microbiome composition. PPIs are widely used to treat heartburn symptoms, it is estimated that about $25 \%$ of the population takes medication from this drug group when necessary [113]. According to Dutch data, 7\% of the population in The Netherlands used omeprazole in 2013 [114]. PPI use is especially overrepresented in obese persons, elderly people, patients with non-alcoholic fatty liver disease or non-alcoholic steatohepatitis (NAFLD, NASH), irritable bowel syndrome (IBS) and inflammatory bowel disease (IBD). A meta-analysis of 300,000 patients showed

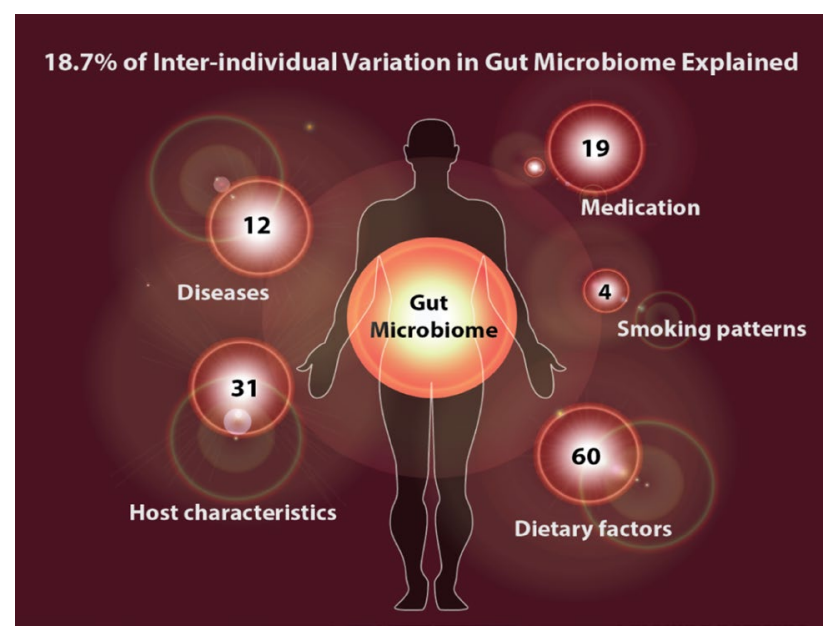

Fig. 4 Explained variance of microbiome composition by different factors that PPI use was associated with 65\% increase in Clostridium difficile-associated diarrhea, and PPIs increased the risk of $C$. difficile recurrence. According to another metaanalysis of 11,280 patients, PPIs increased the risk of Salmonella, Campylobacter ant other enteric infections [115-118]. Furthermore, PPI use is associated with profound alterations in the gut microbiome, namely a lower diversity can be observed in PPI users. Since PPIs can have negative effect on microbiota composition, it has been proposed that microbiome research in humans should be corrected for PPI use.

A strong correlation of antibiotics has been described with several species of the microbiome. Among others, antibiotics decrease occurrence of Bifidobacterium longum, Bifidobacterium adolescentes, Roseburia inulinivorans and increase occurrence of Lachnospiraceae bacterium 2_1_58FAA and Veillonella parvula. However, in Dutch population the effect of antibiotics on the population level is less strong, than the effect of PPI: the reason for that is low consumption of antibiotics in the Netherlands compared to other countries. Regarding the correlation of statin use with microbiome composition, research is emerging (e.g., Dorea longicatena is negatively associated with statin use), with many questions to be answered. This effect can partly be explained by the association of microbiome with lipid levels that have been identified in several human and mouse studies [119].

Currently, what we know is that several drug groups can have a strong effect on gut microbiome. As discussed above, PPIs are not benign in this respect, since they can cause unhealthy changes in the microbiome. Antibiotics might have a small effect on population scale, but this can be substantial for the individuals. Further research faces challenges in dissecting the complex effect of diet, disease, and medication.

\section{Clinical assessment of interactions of drugs with nutrients: how to approach}

As noted before, elderly people are vulnerable in many aspects, including nutritional status. This warrants a systematic assessment of nutrient-drug interactions, starting with classes of drugs that are used in the common complex disorders that account for the global burden of disease of our time. Today, medicine is clearly pharma-dominated where nutrition plays only a confounder role. However, especially lifestyle-related disorders would need a better integrated approach of food and pharma, even for conditions where lifestyle management is already incorporated in clinical guidelines, such as hypertension and diabetes. Clinical trials currently assess adverse effects only, nutritional background is 
not specified. There is no search for the best nutritional background that fits the study purpose, even for conditions where evidence for interaction of nutritional factors with pharmacological efficacy, or adverse drug effects, was available early in the course of drug development, as was the case for interaction of renin-angiotensin-aldosterone-blockade and sodium intake [120]. Accordingly, investigator brochures focus on toxicity, without assessment of favorable or adverse nutritional conditions that blunt or potentiate drug effect. Post-marketing surveillance and guidelines also address adverse effects; nutritional recommendations are alongside but not integrated with pharmacological recommendations. Moreover, quality indicators focus on drug prescription only. Taken together, neglect of nutritional factors can result in lack of efficacy of pharmacotherapy, even when the latter is considered standard of care, based on evidence from randomized clinical trials, and adopted in current guidelines [121]. Proper consideration of nutritional status in drug action, and assessment of adverse drug effects on nutritional status clearly requires a paradigm change towards inclusion of nutritional assessment throughout the stages of drug development and evaluation, ranging from early stage experimental work, through clinical investigations, approval and eventually post-marketing surveillance. Spontaneous reporting of adverse drug effects in clinical practice should be stimulated, with special attention for nutrition-related events. Strategies for individual patients should include development of drug review protocols, and assessment and integration of nutritional factors and consequences. If possible, clinicians should standardly screen for malnutrition, register measurements of global nutrition status and of dietary supplements used. The proposed framework for categorizing DNIs can be of help structuring these consequences. A necessary condition for working with this framework is more nutritional knowledge amongst health care practitioners and researchers, which might be achieved by integrating nutritional education in the curricula of schools of medicine and pharmacology. Development of a toolbox of nutritional readouts would greatly facilitate this process. One should start with "usual suspects" as models for a systematic approach and use "low hanging fruits" (e.g., quantified assessment of diet) for concept development and relatively rapid benefit. In addition, 24-h urine analysis as a tool for nutritional profiling would allow assessments that are more sophisticated. Examples from several disciplines (e.g., oncology and nephrology) have demonstrated the huge potential gains of proper integration of nutritional and pharmacological management, therefore, engagement of both pharma and food industry in food-drug interactions is of paramount importance for further development. Finally, communicating the outcomes of these recommendations is of crucial interest to integrate DNIs in health care.

\section{Conclusions}

Since from public health perspective the field of drug-nutrition interactions is currently highly undervalued and overlooked, this paper addressed various aspects of this complex topic. We still observe a continuous progress in increasing life expectancy, however, during the last two decades several considerable changes occurred. One example is that in the US, the life expectancy of Caucasians is decreasing, most probably due to lifestyle-related factors like increased stress, drugs abuse, lower socioeconomic status, unhealthy diet and increased prevalence of obesity, leading to the current diabetes epidemic, NAFLD, etc. To reverse this trend and achieve a positive change and improvement in public health, multiple conditions are simultaneously required, most importantly collaboration among all relevant stakeholders and inevitably the governmental will to make improvements happen. Multimorbidity among adults is rapidly escalating with age, in the elderly it is the common status, not an exception any more. This consequently leads to polypharmacy, increasing the risk for major drug-drug interactions. Vitamins as essential nutrients have central functions in metabolism, thus interactions and insufficient availability of vitamins can result in critical impairments of metabolism. Although multiple examples of interactions of drugs with micronutrients are reported, only a small part has been addressed in this paper. These are relatively well-studied cases, but multi-drug interactions have not been tested so far. The question is what can be done in this respect to the benefit of the patients. Since food-pharma-health are interconnected domains, one of the most important actions is to generate higher awareness in the medical community of the potential interactions, e.g., by integrating this topic into the education plans of medical students. On the other hand, nutritional sciences and food industry should also develop an open mind towards interaction and collaboration with the medical domains. It is of paramount importance to further advocate for the integration of drug-nutrition evaluation processes as an essential part of the drug research and development. Strategies for the individual patients should also be developed, by installing drug review protocols, screening for malnutrition and integrating this topic in the general medical advice.

Acknowledgements University Medical Center Groningen and DSM Nutritional Products Ltd. made the organization of the workshop "Public Health Relevance of Drug-Nutrient Interactions" possible. The above organizations have funded the workshop and supported participants' travel grants and accommodations. 


\section{Compliance with ethical standards}

Conflict of interest University Medical Center Groningen and DSM Nutritional Products Ltd. made the organization of the workshop "Public Health Relevance of Drug-Nutrient Interactions" possible. The above organizations have funded the workshop and supported travel grants and accommodations for Gerjan Navis, Martin H. de Borst, Clemens von Schacky, Anne Claire B. van Orten-Luiten and Alexandra Zhernakova. Renger F. Witkamp, André Janse and Stephan J. L. Bakker did not participate at the workshop. Szabolcs Peter, Peter Weber and Manfred Eggersdorfer are employees of DSM Nutritional Products Ltd. Gerjan Navis, Martin H. de Borst, Clemens von Schacky, Anne Claire B. van Orten-Luiten, Alexandra Zhernakova, Renger F. Witkamp, André Janse and Stephan J. L. Bakker declare that they have no conflict of interest.

Open Access This article is distributed under the terms of the Creative Commons Attribution 4.0 International License (http:// creativecommons.org/licenses/by/4.0/), which permits unrestricted use, distribution, and reproduction in any medium, provided you give appropriate credit to the original author(s) and the source, provide a link to the Creative Commons license, and indicate if changes were made.

\section{References}

1. Peter S, Eggersdorfer M, van Asselt D, Buskens E, Detzel P, Freijer K, Koletzko B, Kraemer K, Kuipers F, Neufeld L, Obeid R, Wieser S, Zittermann A, Weber P (2014) Selected nutrients and their implications for health and disease across the lifespan: a roadmap. Nutrients 6(12):6076-6094. doi:10.3390/ nu6126076

2. Peter S, Saris WH, Mathers JC, Feskens E, Schols A, Navis G, Kuipers F, Weber P, Eggersdorfer M (2015) Nutrient status assessment in individuals and populations for healthy agingstatement from an expert workshop. Nutrients 7(12):1049110500. doi:10.3390/nu7125547

3. Troesch B, Biesalski HK, Bos R, Buskens E, Calder PC, Saris WH, Spieldenner J, Verkade HJ, Weber P, Eggersdorfer M (2015) Increased intake of foods with high nutrient density can help to break the intergenerational cycle of malnutrition and obesity. Nutrients 7(7):6016-6037. doi:10.3390/nu7075266

4. Ioannidis JP, Greenland S, Hlatky MA, Khoury MJ, Macleod MR, Moher D, Schulz KF, Tibshirani R (2014) Increasing value and reducing waste in research design, conduct, and analysis. Lancet 383(9912):166-175. doi:10.1016/ S0140-6736(13)62227-8

5. Meems LM, de Borst MH, Postma DS, Vonk JM, Kremer HP, Schuttelaar ML, Rosmalen JG, Weersma RK, Wolffenbuttel BH, Scholtens S, Stolk RP, Kema IP, Navis G, Khan MA, van der Harst P, de Boer RA (2015) Low levels of vitamin D are associated with multimorbidity: results from the LifeLines Cohort Study. Ann Med 47(6):474-481. doi:10.3109/07853890. 2015.1073347

6. Fortin M, Bravo G, Hudon C, Vanasse A, Lapointe L (2005) Prevalence of multimorbidity among adults seen in family practice. Ann Fam Med 3(3):223-228. doi:10.1370/afm.272

7. Raats MM, de Lisette CPGM, Groot Dieneke, van Asselt D (2016) Food for the aging population, 2nd edn. Woodhead Publishing, Elsevier, Duxford

8. Gotzsche PC (ed) (2013) Deadly medicines and organised crime: How big pharma has corrupted healthcare. Radcliffe Publishing Ltd, London
9. Onder G, Petrovic M, Tangiisuran B, Meinardi MC, MarkitoNotenboom WP, Somers A, Rajkumar C, Bernabei R, van der Cammen TJ (2010) Development and validation of a score to assess risk of adverse drug reactions among in-hospital patients 65 years or older: the GerontoNet ADR risk score. Arch Intern Med 170(13):1142-1148. doi:10.1001/archinternmed.2010.153

10. Raats M, de Groot L, van Staveren W (2009) Food for the ageing population, 1st edn. Woodhead Publishing Limited, Cambridge

11. Tache SV, Sonnichsen A, Ashcroft DM (2011) Prevalence of adverse drug events in ambulatory care: a systematic review. Ann Pharmacother 45:977-989

12. van der Hooft CS, Dieleman JP, Siemes C, Aarnoudse AJ, Verhamme KM, Stricker BH, Sturkenboom MC (2008) Adverse drug reaction-related hospitalisations: a population-based cohort study. Pharmacoepidemiol Drug Saf 17(4):365-371. doi: $10.1002 /$ pds. 1565

13. Hazell L, Shakir SA (2006) Under-reporting of adverse drug reactions: a systematic review. Drug Saf 29(5):385-396

14. Andrews EB, Moore N (eds) (2014) Mann's pharmacovigilance, 3rd edn. Wiley Blackwell, New York

15. Boullata JI, Hudson LM (2012) Drug-nutrient interactions: a broad view with implications for practice. J Acad Nutr Diet 112(4):506-517. doi:10.1016/j.jada.2011.09.002

16. Chung M, van Buul VJ, Wilms E, Nellessen N, Brouns FJPH (2014) Nutrition education in European medical schools: results of an international survey. Eur J Clin Nutr 68(7):844-846. doi:10.1038/ejen.2014.75

17. Schnetz MP, Handoko L, Akhtar-Zaidi B, Bartels CF, Pereira CF, Fisher AG, Adams DJ, Flicek P, Crawford GE, Laframboise T, Tesar P, Wei CL, Scacheri PC (2010) CHD7 targets active gene enhancer elements to modulate ES cell-specific gene expression. PLoS Genet 6(7):e1001023. doi:10.1371/journal. pgen. 1001023

18. Adams KM, Kohlmeier M, Zeisel SH (2010) Nutrition education in U.S. medical schools: latest update of a national survey. Acad Med 85(9):1537-1542. doi:10.1097/ ACM.0b013e3181eab71b

19. Qato DM, Wilder J, Schumm L, Gillet V, Alexander G (2016) Changes in prescription and over-the-counter medication and dietary supplement use among older adults in the united states, 2005 vs 2011. JAMA Intern Med 176(4):473-482

20. Gu Q, Dillon CF, Burt VL (2010) Prescription drug use continues to increase: U.S. prescription drug data for 2007-2008. NCHS Data Brief 42:1-8

21. Boullata JI (2013) Drug and nutrition interactions: not just food for thought. J Clin Pharm Ther 38(4):269-271. doi:10.1111/ jcpt. 12075

22. Ratain MJ, Cohen EE (2007) The value meal: how to save $\$ 1,700$ per month or more on lapatinib. J Clin Oncol 25(23):3397-3398. doi:10.1200/JCO.2007.12.0758

23. Ryan CJ, Smith MR, Fong L, Rosenberg JE, Kantoff P, Raynaud F, Martins V, Lee G, Kheoh T, Kim J, Molina A, Small EJ (2010) Phase I clinical trial of the CYP17 inhibitor abiraterone acetate demonstrating clinical activity in patients with castration-resistant prostate cancer who received prior ketoconazole therapy. J Clin Oncol 28(9):1481-1488. doi:10.1200/ JCO.2009.24.1281

24. Peklar J, Henman MC, Kos M, Richardson K, Kenny RA (2014) Concurrent use of drugs and supplements in a community-dwelling population aged 50 years or more: potential benefits and risks. Drugs Aging 31(7):527-540. doi:10.1007/ s40266-014-0180-6

25. Daenen LG, Cirkel GA, Houthuijzen JM, Gerrits J, Oosterom I, Roodhart JM, van Tinteren H, Ishihara K, Huitema AD, Verhoeven-Duif NM, Voest EE (2015) Increased plasma 
levels of chemoresistance-inducing fatty acid 16:4(n-3) after consumption of fish and fish oil. JAMA Oncol 1(3):350-358. doi:10.1001/jamaoncol.2015.0388

26. de Boer A, van Hunsel F, Bast A (2015) Adverse fooddrug interactions. Regul Toxicol Pharmacol 73(3):859-865. doi:10.1016/j.yrtph.2015.10.009

27. Jyrkka J, Mursu J, Enlund H, Lonnroos E (2012) Polypharmacy and nutritional status in elderly people. Curr Opin Clin Nutr Metab Care 15(1):1-6. doi:10.1097/MCO.0b013e32834d155a

28. Heuberger R (2012) Polypharmacy and food-drug interactions among older persons: a review. J Nutr Gerontol Geriatr 31(4):325-403. doi:10.1080/21551197.2012.729902

29. van Orten-Luiten AC, Janse A, Dhonukshe-Rutten RA, Witkamp RF (2016) Vitamin D deficiency as adverse drug reaction? A cross-sectional study in Dutch geriatric outpatients. Eur J Clin Pharmacol 72(5):605-614. doi:10.1007/ s00228-016-2016-2

30. Grober U, Kisters K (2012) Influence of drugs on vitamin D and calcium metabolism. Dermatoendocrinology 4(2):158-166. doi:10.4161/derm.20731

31. Holzgreve W, Pietrzik K, Koletzko B, Eckmann-Scholz C (2012) Adding folate to the contraceptive pill: a new concept for the prevention of neural tube defects. J Matern Fetal Neonatal Med 25(9):1529-1536. doi:10.3109/14767058.2011.648672

32. Ars CL, Nijs IM, Marroun HE, Muetzel R, Schmidt M, Steenweg-de Graaff J, van der Lugt A, Jaddoe VW, Hofman A, Steegers EA, Verhulst FC, Tiemeier H, White T (2016) Prenatal folate, homocysteine and vitamin B12 levels and child brain volumes, cognitive development and psychological functioning: the Generation R Study. Br J Nutr. doi:10.1017/ S0007114515002081

33. De-Regil LM, Fernandez-Gaxiola AC, Dowswell T, Pena-Rosas JP (2010) Effects and safety of periconceptional folate supplementation for preventing birth defects. Cochrane Database Syst Rev 10:CD007950. doi:10.1002/14651858.CD007950.pub2

34. Daly LE, Kirke PN, Molloy A, Weir DG, Scott JM (1995) Folate levels and neural tube defects. Implications for prevention. JAMA 274(21):1698-1702

35. Shere M, Bapat P, Nickel C, Kapur B, Koren G (2015) Association between use of oral contraceptives and folate status: a systematic review and meta-analysis. J Obstet Gynaecol Can 37(5):430-438

36. Lambie DG, Johnson RH (1985) Drugs and folate metabolism. Drugs 30(2):145-155

37. Wilson SM, Bivins BN, Russell KA, Bailey LB (2011) Oral contraceptive use: impact on folate, vitamin $\mathrm{B}(6)$, and vitamin B(1)(2) status. Nutr Rev 69(10):572-583. doi:10.1111/j.1753-4887.2011.00419.x

38. Bart S Sr, Marr J, Diefenbach K, Trummer D, SampsonLanders C (2012) Folate status and homocysteine levels during a 24-week oral administration of a folate-containing oral contraceptive: a randomized, double-blind, active-controlled, parallelgroup, US-based multicenter study. Contraception 85(1):42-50. doi:10.1016/j.contraception.2011.05.013

39. Diefenbach K, Trummer D, Ebert F, Lissy M, Koch M, Rohde B, Blode H (2013) EE-drospirenone-levomefolate calcium versus EE-drospirenone + folic acid: folate status during 24 weeks of treatment and over 20 weeks following treatment cessation. Int J Womens Health 5:149-163. doi:10.2147/IJWH.S37254

40. Shere M, Bapat P, Nickel C, Kapur B, Koren G (2015) The effectiveness of folate-fortified oral contraceptives in maintaining optimal folate levels to protect against neural tube defects: a systematic review. J Obstet Gynaecol Can 37(6):527-533

41. Mitsnefes MM (2012) Cardiovascular disease in children with chronic kidney disease. J Am Soc Nephrol 23(4):578-585. doi:10.1681/ASN.2011111115
42. Schmidt N, Brandsch C, Kuhne H, Thiele A, Hirche F, Stangl GI (2012) Vitamin D receptor deficiency and low vitamin D diet stimulate aortic calcification and osteogenic key factor expression in mice. PLoS One 7(4):e35316. doi:10.1371/journal.pone. 0035316

43. Mathew S, Lund RJ, Chaudhary LR, Geurs T, Hruska KA (2008) Vitamin D receptor activators can protect against vascular calcification. J Am Soc Nephrol 19(8):1509-1519. doi:10.1681/ASN.2007080902

44. van Ballegooijen AJ, Gansevoort RT, Lambers-Heerspink HJ, de Zeeuw D, Visser M, Brouwer IA, Kema IP, de Borst MH, Bakker SJ, Joosten MM (2015) Plasma 1,25-dihydroxyvitamin $\mathrm{D}$ and the risk of developing hypertension: the prevention of renal and vascular end-stage disease study. Hypertension 66(3):563-570. doi:10.1161/ HYPERTENSIONAHA.115.05837

45. Keyzer CA, van Breda GF, Vervloet MG, de Jong MA, Laverman GD, Hemmelder MH, Janssen WM, Lambers Heerspink HJ, Kwakernaak AJ, Bakker SJ, Navis G, de Borst MH, Holland Nephrology Study Network (2016) Effects of vitamin D receptor activation and dietary sodium restriction on residual albuminuria in CKD: the ViRTUE-CKD trial. J Am Soc Nephrol. doi:10.1681/ASN.2016040407

46. Schottker B, Jorde R, Peasey A, Thorand B, Jansen EH, Groot L, Streppel M, Gardiner J, Ordonez-Mena JM, Perna L, Wilsgaard T, Rathmann W, Feskens E, Kampman E, Siganos G, Njolstad I, Mathiesen EB, Kubinova R, Pajak A, Topor-Madry R, Tamosiunas A, Hughes M, Kee F, Bobak M, Trichopoulou A, Boffetta P, Brenner H, Consortium on Health and Ageing: Network of Cohorts in Europe and the United States (2014) Vitamin D and mortality: meta-analysis of individual participant data from a large consortium of cohort studies from Europe and the United States. BMJ 348:g3656. doi:10.1136/bmj.g3656

47. Bjelakovic G, Gluud LL, Nikolova D, Whitfield K, Wetterslev J, Simonetti RG, Bjelakovic M, Gluud C (2014) Vitamin D supplementation for prevention of mortality in adults. Cochrane Database Syst Rev 1:CD007470. doi:10.1002/14651858. CD007470.pub3

48. Bolland MJ, Grey A, Gamble GD, Reid IR (2014) The effect of vitamin D supplementation on skeletal, vascular, or cancer outcomes: a trial sequential meta-analysis. Lancet Diabetes Endocrinol 2(4):307-320. doi:10.1016/S2213-8587(13)70212-2

49. Bischoff-Ferrari HA, Orav EJ, Willett WC, Dawson-Hughes B (2014) The effect of vitamin D supplementation on skeletal, vascular, or cancer outcomes. Lancet Diabetes Endocrinol 2(5):363-364. doi:10.1016/S2213-8587(14)70096-8

50. Anagnostis P, Karras SN, Athyros VG, Annweiler C, Karagiannis A (2014) The effect of vitamin D supplementation on skeletal, vascular, or cancer outcomes. Lancet Diabetes Endocrinol 2(5):362-363. doi:10.1016/S2213-8587(14)70095-6

51. Grant WB (2014) The effect of vitamin D supplementation on skeletal, vascular, or cancer outcomes. Lancet Diabetes Endocrinol 2(5):364. doi:10.1016/S2213-8587(14)70098-1

52. Luo G, Ducy P, McKee MD, Pinero GJ, Loyer E, Behringer RR, Karsenty G (1997) Spontaneous calcification of arteries and cartilage in mice lacking matrix GLA protein. Nature 386(6620):78-81. doi:10.1038/386078a0

53. Spronk HM, Soute BA, Schurgers LJ, Thijssen HH, De Mey JG, Vermeer C (2003) Tissue-specific utilization of menaquinone-4 results in the prevention of arterial calcification in warfarintreated rats. J Vasc Res 40(6):531-537

54. McCabe KM, Booth SL, Fu X, Shobeiri N, Pang JJ, Adams MA, Holden RM (2013) Dietary vitamin K and therapeutic warfarin alter the susceptibility to vascular calcification in experimental chronic kidney disease. Kidney Int 83(5):835844. doi:10.1038/ki.2012.477 
55. Kruger T, Oelenberg S, Kaesler N, Schurgers LJ, van de Sandt AM, Boor P, Schlieper G, Brandenburg VM, Fekete BC, Veulemans V, Ketteler M, Vermeer C, Jahnen-Dechent W, Floege J, Westenfeld R (2013) Warfarin induces cardiovascular damage in mice. Arterioscler Thromb Vasc Biol 33(11):2618-2624. doi:10.1161/ATVBAHA.113.302244

56. Pivin E, Ponte B, Pruijm M, Ackermann D, Guessous I, Ehret G, Liu YP, Drummen NE, Knapen MH, Pechere-Bertschi A, Paccaud F, Mohaupt M, Vermeer C, Staessen JA, Vogt B, Martin PY, Burnier M, Bochud M (2015) Inactive matrix Glaprotein is associated with arterial stiffness in an adult population-based study. Hypertension 66(1):85-92. doi:10.1161/ HYPERTENSIONAHA.115.05177

57. Ueland T, Gullestad L, Dahl CP, Aukrust P, Aakhus S, Solberg OG, Vermeer C, Schurgers LJ (2010) Undercarboxylated matrix Gla protein is associated with indices of heart failure and mortality in symptomatic aortic stenosis. J Intern Med 268(5):483492. doi:10.1111/j.1365-2796.2010.02264.x

58. Mayer O Jr, Seidlerova J, Bruthans J, Filipovsky J, Timoracka K, Vanek J, Cerna L, Wohlfahrt P, Cifkova R, Theuwissen E, Vermeer C (2014) Desphospho-uncarboxylated matrix Glaprotein is associated with mortality risk in patients with chronic stable vascular disease. Atherosclerosis 235(1):162-168. doi:10.1016/j.atherosclerosis.2014.04.027

59. Schurgers LJ, Barreto DV, Barreto FC, Liabeuf S, Renard C, Magdeleyns EJ, Vermeer C, Choukroun G, Massy ZA (2010) The circulating inactive form of matrix gla protein is a surrogate marker for vascular calcification in chronic kidney disease: a preliminary report. Clin J Am Soc Nephrol 5(4):568-575. doi:10.2215/CJN.07081009

60. Keyzer CA, Vermeer C, Joosten MM, Knapen MH, Drummen NE, Navis G, Bakker SJ, de Borst MH (2015) Vitamin K status and mortality after kidney transplantation: a cohort study. Am J Kidney Dis 65(3):474-483. doi:10.1053/j.ajkd.2014.09.014

61. Krueger T, Schlieper G, Schurgers L, Cornelis T, Cozzolino M, Jacobi J, Jadoul M, Ketteler M, Rump LC, Stenvinkel P, Westenfeld R, Wiecek A, Reinartz S, Hilgers RD, Floege J (2014) Vitamin K1 to slow vascular calcification in haemodialysis patients (VitaVasK trial): a rationale and study protocol. Nephrol Dial Transplant 29(9):1633-1638. doi:10.1093/ndt/gft459

62. Vossen LM, Schurgers LJ, van Varik BJ, Kietselaer BL, Vermeer C, Meeder JG, Rahel BM, van Cauteren YJ, Hoffland GA, Rennenberg RJ, Reesink KD, de Leeuw PW, Kroon AA (2015) Menaquinone-7 supplementation to reduce vascular calcification in patients with coronary artery disease: rationale and study protocol (VitaK-CAC Trial). Nutrients 7(11):8905-8915. doi: $10.3390 /$ nu7115443

63. Schlieper G, Westenfeld R, Kruger T, Cranenburg EC, Magdeleyns EJ, Brandenburg VM, Djuric Z, Damjanovic T, Ketteler M, Vermeer C, Dimkovic N, Floege J, Schurgers LJ (2011) Circulating nonphosphorylated carboxylated matrix gla protein predicts survival in ESRD. J Am Soc Nephrol 22(2):387-395. doi:10.1681/ASN.2010040339

64. Geleijnse JM, Vermeer C, Grobbee DE, Schurgers LJ, Knapen MH, van der Meer IM, Hofman A, Witteman JC (2004) Dietary intake of menaquinone is associated with a reduced risk of coronary heart disease: the Rotterdam Study. J Nutr 134(11):3100-3105

65. Pasch A, Farese S, Graber S, Wald J, Richtering W, Floege J, Jahnen-Dechent W (2012) Nanoparticle-based test measures overall propensity for calcification in serum. J Am Soc Nephrol 23(10):1744-1752. doi:10.1681/ASN.2012030240

66. Smith ER, Ford ML, Tomlinson LA, Bodenham E, McMahon LP, Farese S, Rajkumar C, Holt SG, Pasch A (2014) Serum calcification propensity predicts all-cause mortality in predialysis CKD. J Am Soc Nephrol 25(2):339348. doi:10.1681/ASN.2013060635

67. Keyzer CA, de Borst MH, van den Berg E, Jahnen-Dechent W, Arampatzis S, Farese S, Bergmann IP, Floege J, Navis G, Bakker SJ, van Goor H, Eisenberger U, Pasch A (2016) Calcification propensity and survival among renal transplant recipients. J Am Soc Nephrol 27(1):239-248. doi:10.1681/ ASN.2014070670

68. Archer E, Hand GA, Blair SN (2013) Validity of U.S. nutritional surveillance: National Health and Nutrition Examination Survey caloric energy intake data, 1971-2010. PLoS One 8(10):e76632. doi:10.1371/journal.pone.0076632

69. Kohler A, Bittner D, Low A, von Schacky C (2010) Effects of a convenience drink fortified with n-3 fatty acids on the n-3 index. Br J Nutr 104(5):729-736. doi:10.1017/S0007114510001054

70. Fabian CJ, Kimler BF, Hursting SD (2015) Omega-3 fatty acids for breast cancer prevention and survivorship. Breast Cancer Res 17:62. doi:10.1186/s13058-015-0571-6

71. Davidson MH, Johnson J, Rooney MW, Kyle ML, Kling DF (2012) A novel omega-3 free fatty acid formulation has dramatically improved bioavailability during a low-fat diet compared with omega-3-acid ethyl esters: the ECLIPSE (Epanova((R)) compared to Lovaza $((\mathrm{R}))$ in a pharmacokinetic single-dose evaluation) study. J Clin Lipidol 6(6):573-584. doi:10.1016/j. jacl.2012.01.002

72. Harris WS (2007) International recommendations for consumption of long-chain omega-3 fatty acids. J Cardiovasc Med (Hagerstown) 8(Suppl 1):S50-S52. doi:10.2459/01. JCM.0000289274.64933.45

73. Harris WS, von Schacky C, Park Y (2013) Standardizing methods for assessing omega-3 fatty acid biostatus. In: McNamara RK (ed) The omega-3 fatty acid deficiency syndrome: opportunities for disease prevention. Nova Science Publishers, USA

74. Harris WS, Sands SA, Windsor SL, Ali HA, Stevens TL, Magalski A, Porter CB, Borkon AM (2004) Omega-3 fatty acids in cardiac biopsies from heart transplantation patients: correlation with erythrocytes and response to supplementation. Circulation 110(12):1645-1649. doi:10.1161/01.CIR.0000142292.10048. B2

75. Arnold C, Markovic M, Blossey K, Wallukat G, Fischer R, Dechend R, Konkel A, von Schacky C, Luft FC, Muller DN, Rothe M, Schunck WH (2010) Arachidonic acid-metabolizing cytochrome P450 enzymes are targets of \{omega\}-3 fatty acids. J Biol Chem 285(43):32720-32733. doi:10.1074/jbc. M110.118406

76. Gurzell EA, Wiesinger JA, Morkam C, Hemmrich S, Harris WS, Fenton JI (2014) Is the omega-3 index a valid marker of intestinal membrane phospholipid EPA + DHA content? Prostaglandins Leukot Essent Fatty Acids 91(3):87-96. doi:10.1016/j. plefa.2014.04.001

77. Roy S, Brasky TM, Belury MA, Krishnan S, Cole RM, Marian C, Yee LD, Llanos AA, Freudenheim JL, Shields PG (2015) Associations of erythrocyte omega-3 fatty acids with biomarkers of omega- 3 fatty acids and inflammation in breast tissue. Int J Cancer 137(12):2934-2946. doi:10.1002/ijc.29675

78. von Schacky C (2015) Omega-3 fatty acids in cardiovascular disease - an uphill battle. Prostaglandins Leukot Essent Fatty Acids 92:41-47. doi:10.1016/j.plefa.2014.05.004

79. Muhlhausler BS, Gibson RA, Yelland LN, Makrides M (2014) Heterogeneity in cord blood DHA concentration: towards an explanation. Prostaglandins Leukot Essent Fatty Acids 91(4):135-140. doi:10.1016/j.plefa.2014.07.013

80. Burr ML, Fehily AM, Gilbert JF, Rogers S, Holliday RM, Sweetnam PM, Elwood PC, Deadman NM (1989) Effects of changes in fat, fish, and fibre intakes on death and myocardial 
reinfarction: diet and reinfarction trial (DART). Lancet 2(8666):757-761

81. Tavazzi L, Maggioni AP, Marchioli R, Barlera S, Franzosi MG, Latini R, Lucci D, Nicolosi GL, Porcu M, Tognoni G, Gissi HFI (2008) Effect of n-3 polyunsaturated fatty acids in patients with chronic heart failure (the GISSI-HF trial): a randomised, double-blind, placebo-controlled trial. Lancet 372(9645):1223-1230. doi:10.1016/S0140-6736(08)61239-8

82. Yokoyama M, Origasa H, Matsuzaki M, Matsuzawa Y, Saito Y, Ishikawa Y, Oikawa S, Sasaki J, Hishida H, Itakura H, Kita T, Kitabatake A, Nakaya N, Sakata T, Shimada K, Shirato K, Japan EPAlisI (2007) Effects of eicosapentaenoic acid on major coronary events in hypercholesterolaemic patients (JELIS): a randomised open-label, blinded endpoint analysis. Lancet 369(9567):1090-1098. doi:10.1016/ S0140-6736(07)60527-3

83. Kulzow N, Witte AV, Kerti L, Grittner U, Schuchardt JP, Hahn A, Floel A (2016) Impact of omega-3 fatty acid supplementation on memory functions in healthy older adults. J Alzheimers Dis 51(3):713-725. doi:10.3233/JAD-150886

84. Haast RA, Kiliaan AJ (2015) Impact of fatty acids on brain circulation, structure and function. Prostaglandins Leukot Essent Fatty Acids 92:3-14. doi:10.1016/j.plefa.2014.01.002

85. Witte AV, Kerti L, Hermannstadter HM, Fiebach JB, Schreiber SJ, Schuchardt JP, Hahn A, Floel A (2014) Long-chain omega-3 fatty acids improve brain function and structure in older adults. Cereb Cortex 24(11):3059-3068. doi:10.1093/cercor/bht163

86. Ismail A (2015) Omega-3s and cognition: dosage matters. http://www.goedomega3.com/index.php/blog/2015/08/omega3s-and-cognition-dosage-matters. Accessed 23 Nov 2016

87. Park Y, Park S, Yi H, Kim HY, Kang SJ, Kim J, Ahn H (2009) Low level of n-3 polyunsaturated fatty acids in erythrocytes is a risk factor for both acute ischemic and hemorrhagic stroke in Koreans. Nutr Res 29(12):825-830. doi:10.1016/j. nutres.2009.10.018

88. Moon HJ, Kim TH, Byun DW, Park Y (2012) Positive correlation between erythrocyte levels of n-3 polyunsaturated fatty acids and bone mass in postmenopausal Korean women with osteoporosis. Ann Nutr Metab 60(2):146-153. doi: $10.1159 / 000337302$

89. Lee AL, Park Y (2013) The association between n-3 polyunsaturated fatty acid levels in erythrocytes and the risk of rheumatoid arthritis in Korean women. Ann Nutr Metab 63(1-2):8895. doi: $10.1159 / 000353120$

90. Zaalberg A, Wielders J, Bulten E, van der Staak C, Wouters A, Nijman H (2016) Relationships of diet-related blood parameters and blood lead levels with psychopathology and aggression in forensic psychiatric inpatients. Crim Behav Ment Health 26(3):196-211. doi:10.1002/cbm.1954

91. Lembke P, Capodice J, Hebert K, Swenson T (2014) Influence of omega-3 (n3) index on performance and wellbeing in young adults after heavy eccentric exercise. J Sports Sci Med 13(1):151-156

92. Langlois K, Ratnayake W (2015) Omega-3 index of Canadian adults. Health Rep 26:3-11

93. Risikobewertung Bf (2016) Gesundheitliche Bewertung von Nahrungsergänzungsmitteln. http://www.bfr.bund.de/de/ gesundheitliche_bewertung_von_nahrungsergaenzungsmitteln-945.html. Accessed 23 Nov 2016

94. Kurisu S, Ishibashi K, Kato Y, Mitsuba N, Dohi Y, Nishioka K, Kihara Y (2013) Effects of lipid-lowering therapy with strong statin on serum polyunsaturated fatty acid levels in patients with coronary artery disease. Heart Vessels 28(1):34-38. doi:10.1007/s00380-011-0213-6

95. Harris JI, Hibbeln JR, Mackey RH, Muldoon MF (2004) Statin treatment alters serum n-3 and n-6 fatty acids in hypercholesterolemic patients. Prostaglandins Leukot Essent Fatty Acids 71(4):263-269. doi:10.1016/j.plefa.2004.06.001

96. Stark KD, Van Elswyk ME, Higgins MR, Weatherford CA, Salem N Jr (2016) Global survey of the omega-3 fatty acids, docosahexaenoic acid and eicosapentaenoic acid in the blood stream of healthy adults. Prog Lipid Res 63:132-152. doi:10.1016/j.plipres.2016.05.001

97. Nozue T, Yamamoto $S$, Tohyama S, Fukui K, Umezawa S, Onishi Y, Kunishima T, Sato A, Nozato T, Miyake S, Takeyama Y, Morino Y, Yamauchi T, Muramatsu T, Hibi K, Terashima M, Michishita I (2013) Effects of serum n-3 to n-6 polyunsaturated fatty acids ratios on coronary atherosclerosis in statin-treated patients with coronary artery disease. Am J Cardiol 111(1):611. doi:10.1016/j.amjcard.2012.08.038

98. Macchia A, Romero M, D’Ettorre A, Tognoni G, Mariani J (2013) Exploratory analysis on the use of statins with or without n-3 PUFA and major events in patients discharged for acute myocardial infarction: an observational retrospective study. PLoS One 8(5):e62772. doi:10.1371/journal.pone.0062772

99. Harris WS (2007) Expert opinion: omega-3 fatty acids and bleeding-cause for concern? Am J Cardiol 99(6A):44C-46C. doi:10.1016/j.amjcard.2006.11.021

100. Gross BW, Gillio M, Rinehart CD, Lynch CA, Rogers FB (2017) Omega-3 fatty acid supplementation and warfarin: a lethal combination in traumatic brain injury. J Trauma Nurs 24(1):15-18. doi:10.1097/JTN.0000000000000256

101. Chowdhury R, Warnakula S, Kunutsor S, Crowe F, Ward HA, Johnson L, Franco OH, Butterworth AS, Forouhi NG, Thompson SG, Khaw KT, Mozaffarian D, Danesh J, Di Angelantonio E (2014) Association of dietary, circulating, and supplement fatty acids with coronary risk: a systematic review and meta-analysis. Ann Intern Med 160(6):398-406. doi:10.7326/ M13-1788

102. Reiner MF, Stivala S, Limacher A, Bonetti NR, Mean M, Egloff M, Rodondi N, Aujesky D, von Schacky C, Luscher TF, Camici GG, Beer JH (2017) Omega-3 fatty acids predict recurrent venous thromboembolism or total mortality in elderly patients with acute venous thromboembolism. J Thromb Haemost 15(1):47-56. doi:10.1111/jth. 13553

103. Salisbury AC, Harris WS, Amin AP, Reid KJ, O'Keefe JH Jr, Spertus JA (2012) Relation between red blood cell omega-3 fatty acid index and bleeding during acute myocardial infarction. Am J Cardiol 109(1):13-18. doi:10.1016/j. amjcard.2011.07.063

104. Nandivada P, Anez-Bustillos L, O'Loughlin AA, Mitchell PD, Baker MA, Dao DT, Fell GL, Potemkin AK, Gura KM, Neufeld EJ, Puder M (2016) Risk of post-procedural bleeding in children on intravenous fish oil. Am J Surg. doi:10.1016/j. amjsurg.2016.10.026

105. Nakagawa I, Yokoyama S, Omoto K, Takeshima Y, Matsuda R, Nishimura F, Yamada S, Yokota H, Motoyama Y, Park YS, Nakase H (2016) Omega-3 fatty acid Ethyl Esters suppress cerebral vasospasm and improve clinical outcome following aneurysmal subarachnoid hemorrhage. World Neurosurg. doi:10.1016/j.wneu.2016.12.018

106. Wen L, Ley RE, Volchkov PY, Stranges PB, Avanesyan L, Stonebraker AC, Hu C, Wong FS, Szot GL, Bluestone JA, Gordon JI, Chervonsky AV (2008) Innate immunity and intestinal microbiota in the development of Type 1 diabetes. Nature 455(7216):1109-1113. doi:10.1038/nature07336

107. Lee YK, Menezes JS, Umesaki Y, Mazmanian SK (2011) Proinflammatory T-cell responses to gut microbiota promote experimental autoimmune encephalomyelitis. Proc Natl Acad Sci USA 108(Suppl 1):4615-4622. doi:10.1073/pnas.1000082107

108. Machiels K, Joossens M, Sabino J, De Preter V, Arijs I, Eeckhaut V, Ballet V, Claes K, Van Immerseel F, Verbeke K, 
Ferrante M, Verhaegen J, Rutgeerts P, Vermeire S (2014) A decrease of the butyrate-producing species Roseburia hominis and Faecalibacterium prausnitzii defines dysbiosis in patients with ulcerative colitis. Gut 63(8):1275-1283. doi:10.1136/ gutjnl-2013-304833

109. Scher JU, Sczesnak A, Longman RS, Segata N, Ubeda C, Bielski C, Rostron T, Cerundolo V, Pamer EG, Abramson SB, Huttenhower C, Littman DR (2013) Expansion of intestinal Prevotella copri correlates with enhanced susceptibility to arthritis. Elife 2:e01202. doi:10.7554/eLife.01202

110. Scholtens S, Smidt N, Swertz MA, Bakker SJ, Dotinga A, Vonk JM, van Dijk F, van Zon SK, Wijmenga C, Wolffenbuttel BH, Stolk RP (2015) Cohort profile: LifeLines, a three-generation cohort study and biobank. Int J Epidemiol 44(4):1172-1180. doi:10.1093/ije/dyu229

111. Tigchelaar EF, Zhernakova A, Dekens JA, Hermes G, Baranska A, Mujagic Z, Swertz MA, Munoz AM, Deelen P, Cenit MC, Franke L, Scholtens S, Stolk RP, Wijmenga C, Feskens EJ (2015) Cohort profile: LifeLines DEEP, a prospective, general population cohort study in the northern Netherlands: study design and baseline characteristics. BMJ Open 5(8):e006772. doi:10.1136/bmjopen-2014-006772

112. Zhernakova A, Kurilshikov A, Bonder MJ, Tigchelaar EF, Schirmer M, Vatanen T, Mujagic Z, Vila AV, Falony G, VieiraSilva S, Wang J, Imhann F, Brandsma E, Jankipersadsing SA, Joossens M, Cenit MC, Deelen P, Swertz MA, LifeLines cohort study, Weersma RK, Feskens EJ, Netea MG, Gevers D, Jonkers D, Franke L, Aulchenko YS, Huttenhower C, Raes J, Hofker MH, Xavier RJ, Wijmenga C, Fu J (2016) Populationbased metagenomics analysis reveals markers for gut microbiome composition and diversity. Science 352(6285):565-569. doi:10.1126/science.aad3369

113. Moayyedi P, Talley NJ (2006) Gastro-oesophageal reflux disease. Lancet 367(9528):2086-2100. doi:10.1016/ S0140-6736(06)68932-0
114. Statistics FfP (2014) Facts and figures 2014. Foundation for Pharmaceutical Statistics, The Hague

115. McDonald EG, Milligan J, Frenette C, Lee TC (2015) Continuous proton pump inhibitor therapy and the associated risk of recurrent Clostridium difficile infection. JAMA Intern Med 175(5):784-791. doi:10.1001/jamainternmed.2015.42

116. Bouwknegt M, van Pelt W, Kubbinga ME, Weda M, Havelaar AH (2014) Potential association between the recent increase in campylobacteriosis incidence in the Netherlands and proton-pump inhibitor use-an ecological study. Euro Surveill 19(32):20873

117. Leonard J, Marshall JK, Moayyedi P (2007) Systematic review of the risk of enteric infection in patients taking acid suppression. Am J Gastroenterol 102(9):2047-2056. doi:10.1111/ j. 1572-0241.2007.01275.x (quiz 2057)

118. Janarthanan S, Ditah I, Adler DG, Ehrinpreis MN (2012) Clostridium difficile-associated diarrhea and proton pump inhibitor therapy: a meta-analysis. Am J Gastroenterol 107(7):10011010. doi:10.1038/ajg.2012.179

119. Fu J, Bonder MJ, Cenit MC, Tigchelaar EF, Maatman A, Dekens JA, Brandsma E, Marczynska J, Imhann F, Weersma RK, Franke L, Poon TW, Xavier RJ, Gevers D, Hofker MH, Wijmenga C, Zhernakova A (2015) The gut microbiome contributes to a substantial proportion of the variation in blood lipids. Circ Res 117(9):817-824. doi:10.1161/CIRCRESAHA.115.306807

120. Humalda JK, Navis G (2014) Dietary sodium restriction: a neglected therapeutic opportunity in chronic kidney disease. Curr Opin Nephrol Hypertens 23(6):533-540. doi:10.1097/ MNH.0000000000000073

121. Heerspink HL, Ritz E (2012) Sodium chloride intake: is lower always better? J Am Soc Nephrol 23(7):1136-1139. doi:10.1681/ASN.2012010099 